As opcões propostas e as inevitáveis controvérsias que teriam de sugerir, abrem um vasto leque de alternativas e debates; e é exatamente este o principal mérito de uma obra como esta, que traz os problemas de finanças públicas para o centro das atenções dos que se preocupam com o futuro da sociedade capitalista.

Amarilis Maier Sampaio

\footnotetext{
* Esta resenha for realizada sob a orientação acadêmica do Prof. Eurico Korff, a
} quem agradeço o valioso apoio.

Neja sobre o assunto artigo de Laffer, Arthur B. O papel dos tributos e dos en. cargos na economia de mercado. In Visão, p. 83-6, 17 out. 1977.
Expansão cafeeira e origens da indústria no Brasil

Por Sérgio Silva. São Paulo, AlfaÔmega. $120 \mathrm{p}$.

Originalmente apresentada como tese de mestrado na École Pratique des Hautes Études em 1973, sob o título Le café et l'industrie au Brésil, 1880-1930, o trabalho de Sérgio Silva procura enfatizar "a natureza contraditória das relações café-indústria, de tal modo que a expansão cafeeira determina, ao mesmo tempo, o nascimento da indústria e os limites da industrialização".

O livro é composto de quatro capítulos - 1. Introdução sobre a problemática; 2. Condições históricas da expansão cafeeira; 3. Economia cafeeira; 4. Origens da indústria - sendo que este comentário atentará, basicamente, para alguns aspectos contidos nos capítulos 3 e 4.

Nas primeiras páginas, o autor salienta que a economia cafeeira foi o principal centro da acumulação de capital no Brasil durante o período da República Velha (1889-1930), è que é "... na região do café que o desenvolvimento das relações capitalistas é mais acelerado é é aí que se encontra a maior parte da indústria nascente brasileira (...). Toda a análise da economia cafeeira fundamenta o estudo das relações en- tre economia cafeeira e indústria nascente" (p. 17).

Afirma ainda que a problemática que sustenta este estudo sobre a economia brasileira no período assinalado é a de captar as características específicas de transição capitalista nos países que ocupam uma posição subordinada na economia mundial (p. 27 ).

No terceiro capitulo, Sérgio Silva estuda a economia cafeeira, salientando 0 aumento vertiginoso de sua produção: por volta de 1850 ela atingia, em média, a cifra de 3 milhões de sacas por ano, para, a partir das décadas de 1870 e 1880 principalmente, ultrapassar os milhões de sacas/ano. Então, em suas palavras, "... o café torna-se o centro motor do desenvolvimento do capitalismo no Brasil" (p. 49).

Há de se destacar também o deslocamento geográfico das plantações, pois "... na década de 1880 a produção de São Paulo ultrapassa a do Rio de Janeiro, os planaltos de São Paulo praticamente substituem o Vale do Paraíba (...). A importância do rápido crescimento da produção e desse deslocamento geográfico só poderá ser entendida se considerarmos as simultâneas mudanças ocorridas ao nivel das relações de produção. Ao subir os planaltos de São Paulo, as plantações abandonam o trabalho escravo pelo trabalho assalariado. Com o trabalho assalariado, a produção cafeeira conhece a mecanização (...). Além disso, a possibilidade desse deslocamento é determinada pela construção de uma rede de estradas de ferro bastante importante. Finalmente, o financiamento e a comercialização de uma produção que atinge milhões de sacas implica o desenvolvimento de um sistema comercial relativamente avançado, formado por casas de exportação e uma rede bancária. É fundamentalmente por essas razões que o café se tornou o centro motor do desenvolvimento capitalista no Brasil" (p. 50$)$.

Mas, é no quarto capítulo Origens da indústria - que o 
trabalho de Sérgio Silva se agiganta. Afirmando, no início, que o estudo sobre as origens da indústria no Brasil é "... o estudo da gestação de novas formas de acumulação baseadas no trabalho assalariado e no capital, das condições que determinam historicamente essas novas formas: a economia cafeeira e, através da economia cafeeira, o modo de inserção do Brasil na economia mundial capitalista" ( $p .81$; grifado no originall, o autor delineia alguns pressupostos básicos que nortearão o esquema explicativo deste último capítulo.

Utilizando-se de informações contidas nas estatísticas industriais de 1907 e 1920, evidencia que as chamadas "grandes empresas" "com 100 ou mais operários ou capital igual ou superior a 1.000 contos" lque, de acordo com a taxa média de câmbio de 1907 correspondia a cerca de 64 mil libras) - constituíram a base da nascente indústria nacional. $E$ acrescenta que "o conjunto das empresas com 100 ou mais operários reagrupa, de acordo com os dados do Centro Industrial do Brasil, mais de $85 \%$ do capital, em São Paulo; e cerca de $70 \%$, no antigo Distrito Federal" (p. 83). Assim, essas evidências jogam por terra a tese segundo a qual, durante o período da hegemonia cafeeira, a indústria caracteriza-se por pequenas empresas de tipo artesanal ou pequenas manufaturas voltadas para reduzidos mercados locais.

O ponto basilar da obra é o exame, realizado no tópico "Origens da burguesia industrial", das concepções de vários estudiosos da questão, entre os quais se destacam Santiago Dantas, Rui Mauro Marini, Caio Prado Júnior e Warren Dean. Após resenhar criticamente o pensamento dos autores citados, Sérgio Silva conclui que "para a burguesia industrial nascente, a base de apoio para o início da acumulação não é a pequena empresa industrial, mas o comércio, em particular o grande comércio cujo centro está na atividade de exportação e importação. Do mesmo modo que na exportação, a importação é controlada em parte por empresas estrangeiras. Graças às suas origens sociais, o burguês imigrante encontra facilmente um lugar no grande comércio. Ele torna-se representante de firmas e marcas estrangeiras e se encarrega da distribuição de produtos importados pelo interior do país" (p. 95).

$E$, considerando também os chamados aspectos contraditórios das relações café-indústria, o autor conclui, de modo a discordar de várias teses até agora aceitas, que "... as relações entre o comércio exterior e a economia cafeeira, de um lado, e a indústria nascente, de outro, implicam, ao mesmo tempo, a unidade e a contradição. A unidade está no fato de que o deserivolvimento capitalista baseado na expansão cafeeira provoca o nascimento e um certo desenvolvimento da indústria; a contradição, nos limites impostos ao desenvolvimento da indústria pela própria posição dominante da economia cafeeira na acumulação de capital" (p. 103).

Haveria ainda outros aspectos a serem explorados neste breve comentário, como por exemplo o tratamento dado às estatísticas de 1920, demonstrando que o capital industrial brasileiro era quase todo concentrado nos setores de bens de consumo - cerca de $85,4 \%$ do valor da produção industrial (p. 113) - ou que, graças à importação de equipamentos modernos, o capital industrial brasileiro saltou etapas e adotou, desde o início, técnicas avançadas que possibilitaram uma rentabilidade elevada (p. 114-5).

Concluindo, acredito que o trabalho de Sérgio Silva deve merecer atenção especial por se constituir em sopro inovador às interpretações da história econômica brasileira da República Velha, sendo que sua leitura é enriquecida ainda mais quando se conhece também a tese de doutoramento de João Cardoso de Melo, 0 capitalismo tardio, em especial o tópico "A industrializaão restringida".

Afrânio Mendes Catani

\section{La societé contre l'Etat}

Por Pierre Clastres. Paris, Editions de Minuit, 1974.

"Pendant que les espagnols envoyaient des comissions d'enquête pour rechercher si les indigènes avaient ou non une âme, ces derniers s'employaient à immerger des blancs prisionniers, afin de vérifier, par une surveillance prolongée, si leur cadavre était ou non sujet à la putréfation."

Que interesse pode ter o estudo das organizações indígenas para a análise das organizações contemporâneas? Por que dar atenção a uma obra que, surgida nas franjas da antropologia e, como que possuída de um désir justiceiro, investe contra o estamento e a tradição antropológica?

A obra de Clastres por si própria responde a estas questões. O que faremos aqui será delinear, na medida do possivel, as partes das obra que julgamos apresentar um impacto decisivo no que se pretende entender como formações e processos organizacionais, em particular os que vivemos.

Logo de inicio, é preciso ressaltar o caráter pluridimensional da "agressão" de Clastres, o que quer dizer que, mesmo tendo como fin condutor o pressuposto de que para o estudo de "ce gens là sans foi, sans loi, sans roi..." é neces- 